\title{
A DISCOURSE ANALYSIS OF RHETORICAL STYLE IN RESEARCH ARTICLE INTRODUCTION IN LAW STUDIES WRITTEN BY INTERNATIONAL AUTHORS
}

\author{
Ejontomi Afrizon \\ Universitas Bengkulu \\ ejontomiii@gmail.com \\ Safnil Arsyad \\ Universitas Bengkulu \\ safnilarsyad@gmail.com \\ Zahrida \\ Universitas Bengkulu \\ zahrida@yahoo.com
}

\begin{abstract}
This research is aimed at finding the most dominant move, step and the most common pattern of rhetorical style in Research Article Introduction in Law Studies Written By International Authors. The documentation technique and checklist were used in this research. Fifteen English RA introductions by International authors were analyzed by using disourse analysis technique, using quantitative as well as qualitative method and following Swales's CARS Model (1990). The results show that the authors dominantly use Move 1 (Establishing a territory) and Step 2 of Move 1 (Making Topic Generalisation). The fifteen articles mostly have the same model in leading to understanding to the article introduction. In addition, International authors of English RAs in Law Study prefer describing the phenomena and found the problem based on it to describing the previous research. The most common pattern is Complete Pattern. The articles which belong to Complete Pattern have three moves. While the one which has two moves belong to Semi complete and the one which has one move only belong to incomplete pattern. In conclusion, the articles in the three journals are categorized into appropriate articles in term of discourse structure.
\end{abstract}

Key Words: Undergraduate theses introduction, metadiscourse markers, Indonesian authors, English students. 


\section{ABSTRAK}

Penelitian ini bertujuan untuk mengetahui jenis tahapan, langkah dan pola gaya retorika yang paling dominan dan umum terdapat pada bagian pendahuluan artikel penelitian bidang hukum oleh penulis internasional. Penelitian ini menggunukan teknis ceklis table dan dokumentasi. Lima belas pendahuluan artikel bidang hukum berbahasa Inggris oleh penulis Internasional dianalisis menggunakan metode teknik analisis wacana, menggunakan metode kuantitatif dan kualitatif serta menggunakan teori Model CARS oleh Swales (1990). Hasil penelitian menunjukkan bahwa penulis artikel-artikel tersebut dominan menggunakan Tahapan 1 (Menjelaskan Ruang Lingkup Penelitian) dan Langkah 2 pada Tahap 1 (Membuat Pernyataan Umum). Ke lima belas artikel secara keseluruhan memiliki model yang sama dalam mengarahkan pembaca untuk memahami bagian pendahuluan. Selanjutnya, penulis internasional artikel penelitian bidang hukum berbahasa inggris lebih banyak menjelaskan penomena yang berkaitan dengan topik penelitian dan menemukan masalah dari penomena tersebut dibandingkan dengan mengaitkannya terhadap penelitian terdahulu. Pola gaya retorika yang paling umum ditemukan adalah Pola Lengkap. Artikel yang tergolong dalam pola ini adalah artikel yang memiliki tiga tahap. Sedangkan yang hanya terdiri dari dua digolongkan ke semi lengkap dan yang hanya satu tahap tergolong tidak lengkap. Artikel pada ketiga journal bisa digolongkan ke dalam artikel yang memadai secara struktur wacana dengan mempertimbangkan pola yang paling dominan adalah pola lengkap.

Kata Kunci : Pendahuluan Artikel Penelitian, Gaya Retorika, Penulis Internasional, Bidang Hukum.

\section{INTRODUCTION}

According to Hogne (2006), scientific paper is one of academic products and academic writing is the kind of writing that is required to do in college or university. Meanwhile, Balleste (2003) stated that the results of the research are published in the form of scientific paper. That means when someone conducts a research and then she or he wants to share the findings or results to others, she or he can explain them in scientific paper or research article.

The most important section in a research article (RA) is the introduction section because it is the first section to be read by readers after the abstract and if readers are not impressed in reading this section, they will unlikely continue reading the article (Swales \& Najjar, 1987 ; Safnil, 2001). In other words, introduction section of a RA functions to motivate readers in order to read the whole part of the article and therefore introduction must be written as interestingly and convincingly as possible so the readers will read the entire research article.

According to Belcher (2009 : p. 209), the main purpose of introduction section of a RA is to 'provide enough information for the readers to be able to understand your argument and its stakes.' A similar comment has also been made by Swales and Feak (1994) in which they suggest that the main purpose of introduction section of a RA are two folds : these are to give a logical reason for the article and to provoke readers to read it. The ways writers rhetorically present the argument in their RA introduction will determine whether or not readers are impressed and convinced and whether or not they will continue reading the article. 
The ways writers organize their ideas in RA introductions have become a focus interest of scientific discourse studies recently in the world. Adnan (2009) when he analysed the discourse style of RA introductions in the discipline of education written by Indonesian speakers by using Swales' CARS as a model, he found that out of twenty-one RA introductions in the corpus of his study, none of which fit the discourse style of English RA introduction as suggested by Swales (1990). The main difference, according to Adnan is on the occurrence of Move 1 (establishing a territory) in which the majority of Indonesian RA writers address the importance of their research topic by referring to practical problems experienced by common people or the government rather than by specific relevant discourse community. In addition, none of the Indonesian RA authors, as Adnan claims further, justifies their research projects reported in the RAs by pointing at the gap or 'niche' in the results or findings of previous relevant studies as in Swales' model of Move 2 (establishing a niche). Adnan proposes a modified model of ideal problem solution (IPS) to capture important discourse style of the Indonesian RA introduction sections especially in the discipline of education.

A similar study was conducted by Safnil (2001) that investigated the rhetorical structure of RA introductions written in Indonesian by Indonesian writers in social sciences and humanities and found that the discourse style of the RA introductions in the corpus of his study was different from the one in English as in the CARS model suggested by Swales (1990). According to Safnil, the differences are among other things, that 1) the introduction sections of RAs in Indonesian have more moves and steps than the one in English; 2) move 1 (establishing a territory) in the Indonesian RA introduction is mainly dealt with referring to the government policy to convince readers that the topic of the research project is important; 3) Move 2 (establishing a niche), probably the most important move in the RA introduction because this is where the authors justify the research project reported in the RA, is addressed by simply saying that the topic or the problem is necessary or interesting to investigate.

One of the earliest discourse analysis studies on RA introductions in English written by Indonesian speakers was conducted by Mirahayuni (2002). Mirahayuni analysed the discourse style of three groups of RA introductions (20 English RAs by English speakers, 19 Indonesian RAs by Indonesian speakers, and 19 English RAs by Indonesian speakers) in the field of language teaching. Using CARS of Swales (1990) as a model in the analysis, Mirahayuni found differences particularly between English RA introductions by English native speakers (ENSs) and the ones by Indonesian speakers (NNSs) in terms of the way they introduced and justified their research projects reported in the articles. The ENSs referred to the current state of knowledge and findings of previous relevant research' (p. 29) while the NNSs refered to a more practical problems occuring in the society. In other words, according to Mirahayuni, the NNSs intended their research projects to deal with local problems and to be read by smaller scope of readership. Another difference between the two groups of RAs is the occurrence of 'benefits of the study' in the NNS's RA introductions which is not found in the ENS's RAs or in Swales' CARS model.

Of all the previous research mentioned above, there are not many rhetorical styles studies in the discipline of law area. In fact, the problems of law occur almost everytime in the world. Moreover, many people do the research about law and they need to report the results or findings to other people in the 
form of research article so that means they have to make an introduction as well. While, the rhetorical style or move in that section of law research article is still rarely researched. Among medical, science, and engineer research articles, the law studies is the least research. This is the reason why this study is needed to be done; to see how the RAs published in international journals of law studies especially of their introduction sections are schematically structured.

In particular, this study is aimed at investigating the rhetorical style of research article introduction in law studies written by International author. The purpose of the study is to analyze and identify the moves and steps in introduction section.

\section{METHOD}

This research used checklist and documentation technique. The design of this research is descriptive, using quantitative as well as qualitative data. The quantitative data will be shown in order to show the percentage of occurrences, whereas qualitative data will be shown in order to describe, explain, and illustrate the findings in detail. The processes of identifying communicative units in the introduction section of RAs were done following the procedures suggested by Swales (1990). The data result will be mostly in descriptive explanation. The data will be collected, analyzed, identified and discussed. The researcher will focus on the rhetorical moves or structures in introduction part of law research article.

The corpus of this study is fifteen law research articles published in international journals of law studies. They are fifteen English RAs in law studies area in three international journals published (five RAs from International Journals of International Law coded as IJIL from volume 1,2,3 and issues 1 and 2; five RAs from International Journal of Law and Policy Review coded as
IJLPR from volume 07 Number 1 January 2018; and five RAs from the International Journal of Law and Society coded as IJLS from volume 1 and 2 and issues 1 and 2 year 2018). Those articles will be compiled based on the criteria of accessibility, reputation, and peer review.

The instrument of this research is text analysis by using checklist of moves and steps in research articles introduction. In the checklist, the explanation of each moves and steps will be put in column and each article will have one checklist so that the data can be seen clearly.

There were some steps in doing this research. Each steps will be explained below. There are some procedures in the data analysis, they are: First, collecting the research articles. The researcher will collect 15 research articles from three international journals of law studies. The journals are International Journals of International Law, International Journal of Law and Policy Review, and International Journal of Law and Society. There will be taken five research articles from each journals. Second, reading the research articles and the format or structures of the research articles to decide the main sections. This is for the sake of understanding the research articles format or structure. Third, identifying the move by looking at the paragraph in introduction section and analyzing the steps by looking at the sentences of each paragraph of the introduction section. The researcher will carefully identify the moves and the steps. The processes of identifying communicative units in the introduction section of RAs were done following the procedures suggested by Swales (1990). Fourth, analyzing the common pattern of rhetorical styles in law studies research articles. The category will be devided into three patterns. The first one is Complete Pattern which means the article introduction has all three moves as suggested by Swales. The second one is 
Semi Complete Pattern which means the article introduction has two kinds of moves. While the last one is Incomplete Pattern which means the article introduction has only one move. Fifth, validating the analysis results by including one independent raters in the process of text analysis in order to validate the analysis results. The independent rater who will participate in this study is graduated student from English Education Study Program. Before she does the research, she will be told how to identify the moves and the steps found in the texts based on their background education with examples following the analysis procedures as described above. Then, she will be given two weeks to do the processes of analysis for 5 out of 15 RA introductions (20\%) from the corpus of this study. When there is a disagreement between us in finding the steps and moves in the RA introductions, then we will discuss it to find out the reason for the difference and to produce a better analysis result. Sixth, displaying the data into table and diagram with examples. The researcher will provide the result of the research in the form of table and diagram. Seventh, describing the differences of move and steps pattern among the three different Journals (Internatinal Journals of International Law, International Journal of Law and Policy Review, and International Journal of Law and Society).

\section{RESULT AND DISCUSSION}

\section{Result}

From the results of the 15 RAs in Law Studies, there are Move 1, Move 2, Move 3 based on suggested by Swales found in all RA introductions. In Move 1, all the three steps are found. In Move 2, all the steps are found except Step 1D. In Move 3, all the four steps are found. However, the dominant findings of the move and steps are at Step 2 of Move 1 that is Making Topic
Generalizations and step 1B of Move 3 that is Announcing Present Research.

\section{Move Analysis Result}

Research question number 1 asked about what moves are dominantly used in English Research Articles of Law Study in introduction section.

Table 1. Frequency of Move in RA Introductions

\begin{tabular}{|c|c|c|}
\hline Moves & Frequency & Percentage \\
\hline Move 1 & 15 & $100 \%$ \\
\hline Move 2 & 9 & $60 \%$ \\
\hline Move 3 & 11 & $73 \%$ \\
\hline $\mathbf{N}=15$ & & \\
\hline
\end{tabular}

Table 1 shows the frequency and percentage of moves found in the RAs in the corpus of the study. As can be seen from the table, Move 1 is found in 15 articles (100\%), Move 2 is found in 9 articles (60\%), and Move 3 is found in 11 articles (73\%). This clearly proved that the 15 articles of the three journals in the discipline of Law study written by international author dominantly used Move 1 (Establishing a territory).

\section{Example 1:}

Intoxication has been a hot topic of discussion and experimentation with human beings since. In contemporary society, intoxicants worldwide have been classified as legal and controlled/regulated substances; certain intoxicants are permitted to be used recreationally and clinically, whereas the use, manufacture, or possession of others carries punishment. (IJLPR-3)

In example 1, we can see that it belongs to Move 1 because the author stated 'has been a hot topic' which indicates that the problem of the research is useful, relevant, important, or worth investigating since it forms part of a lively, significant or well- 
established research area. Simply we can say that the research is needed to be researched.

Example 2:

$$
\text { Interpreting and comparing }
$$
Constitutions is a challenging task. Such comparison should be as evaluative as it is descriptive, the latter being an inevitability. Germany is a civil law European country with a Parliamentary form of government. In this article, comparisons are made between the Constitutions of Germany, Austria, and Switzerland.Like Germany, the Constitutions of Austria and Switzerland establish these States as Federal Democratic Republics. All these countries have parliamentary form of governments. (IJIL-1)

In example 2, we can see that it belongs to Move 2 because the author stated 'a challenging task' which indicates that the problem found from the phenomena needed to be researched, discussed and solved since it is still needing further investigation. The way this idea is constructed refers to move 2 .

Example 3 :

This paper focuses on the compelling paradigm of analysis - Human Security - that flows from Cosmopolitanism that emerged in the global dialogue on Human Rights Children's Rights in particular. The discussions started with the theoretical considerations of rights in international law and trace the evolution of the international standard on the Rights of Child in the context of these theories. i.e a child as an individual. The paper further makes an attempt at illustrating Child's Rights as Human Rights based on rights based approach adopted by the UN and analyzed the obligations of the State thereto: to respect, protect and fulfil Rights guaranteed under Child's Rights International Treaties she acceded to. (IJIL-2)
In example 3, we can see that it belongs to Move 3 because the author stated 'This paper focuses on the' and ' the paper further makes an attempt at' which indicate that the paragraph of the articles will solve the problem by providing some solution. In addition, this paragraph indicate the structure of the paper.

\section{Steps Analysis Results}

Research question number 2 asked about what steps are dominantly used in introduction section of English Research Articles of Law Study.

\section{Steps In Move 1}

Table 2. Frequency of Steps of Move 1 in RA Introductions

\begin{tabular}{|c|c|c|}
\hline Step & Frequency & Percentage \\
\hline Step 1 & 2 & $13 \%$ \\
\hline Step 2 & 15 & $100 \%$ \\
\hline Step 3 & 4 & $27 \%$ \\
\hline $\mathbf{N = 1 5}$ & & \\
\hline
\end{tabular}

Table 2 shows the frequency and percentage of steps in Move 1 found in the RAs. From the result, Step 1 is found in only 2 articles (13\%), Step 2 is found in 15 articles (100\%), Step 3 is found in 4 articles (27\%). This clearly proved that the 15 articles of the three journals in the discipline of Law study written by international author dominantly used Step 2 in move 1, that is Making Topic Generalisation.

\section{Example 4:}

A particular constitutional provision is drafted to perform a particular function in a legal system. Comparative constitutional study can help identify -those functions and show how different constitutional provisions serve the same function in different constitutional systems. Such an exposure can help in formulating a better and effective understanding of one's own constitutional 
set up opening up multiple scopes of improvement. (IJIL-1)

The example 4 belongs to Step 1 because it can be seen that the author stated 'can help identify' and 'can help' which indicate that the research of the article is useful and significant to do. It will help to facilitate the readers to understand more about the research field.

\section{Example 5 :}

Undoubtedly, the dumping of toxic waste in Koko, Delta State, in June 1988, and the attendant public outcry against the adverse environmental and human rights consequences was a watershed that culminated in the establishment of modern environmental regulatory regime tailored towards combating pollution and otheracts of environmental degradation in Nigeria. (IJLPR-2)

The example 5 belongs to Step 2 because it can be seen that the author explained a lot about statements concerning the current state of either knowledge, consesus, practice or description. It explained more a lot about the phenomena which indicate that the phenomena creates a gap or problem that is useful and significant to solve.

\section{Example 6 :}

Edmund Leach is a renowned anthropologist who has severely criticized the definitions of other thinkers as being too narrow or restrictive. He states that marriage is not explicable within the parameters of one definition because it consists of a series of rights arising from it. These rights include sexual monopoly, legality of children, joint fund for property to benefit the children, etc. 4 Thus; the concept of "sexual monopoly" is of paramount importance within the realms of marriage. However, this fact is arguable as Polygamy is practices in many cultures like Islam till date. (IJLPR-1)

The example 6 belongs to Step 3 because it can be seen that the author explained what the expert said about the research field and problem. The word ' he states that' clearly shows that the researcher reviewed the expert's opinion.

\section{Steps In Move 2}

Table 3. Frequency of Steps of Move 2 in RA Introductions

\begin{tabular}{|c|c|c|}
\hline Step & Frequency & Percentage \\
\hline Step 1A & 3 & $20 \%$ \\
\hline Step 1B & 2 & $13 \%$ \\
\hline Step 1C & 5 & $33 \%$ \\
\hline Step 1D & - & - \\
\hline $\mathbf{N}=15$ & & \\
\hline
\end{tabular}

Table 3 shows the frequency and percentage of steps in Move 2 found in the RAs. From the results, Step $1 A$ is found in only 3 articles (20\%), Step $1 B$ is found in 2 articles (13\%), Step $1 \mathrm{C}$ is found in 5 articles (33\%) and Step 1D is not found in the articles. This clearly proved that the 15 articles of the three journals in the discipline of law study written by international author dominantly used Step $1 \mathrm{C}$ in Move 2, that is Raising A Question.

\section{Example 7:}

The press in Nigeria and the citizens cannot perform this task without a strong legal backing, as is in the case of United States of America, where in the first Amendment to its Constitution clearly adumbrated, among others, that "the Congress shall make no law abridging the freedom of the press". However, this is not the case in Nigeria. (IJLS-5)

The example 7 belongs to Step $1 \mathrm{~A}$ because it can be seen clearly that the author stated 
'however 'which indicates an opposing viewpoint or pinpoint weaknesses.

\section{Example 8:}

The applicable dispute settlement mechanism is different and the outcome of the future referee may be quite different. So what is the difference between the parties at this time as a result of the local relief through the host country or through international arbitration? Thus, this divergence is in fact a direct conflict between the domestic jurisdiction of the host State and the international jurisdiction of international arbitration. (IJLS-4)

The examplet 8 belongs to Step 1B because it can be seen clearly that the author stated 'may be quite different' which indicates a gap or problem found by the researcher.

\section{Example 9 :}

The Stockholm conference of 19721 basically is one on human environment.The explicit acknowledgement that humanity and nature are in symbiotic relationship i.e. both depend upon each other emphasis both the necessity of a good environment for the survival of humankind and humankind responsibility in protecting the environment. However, the Stockholm Declaration is not simply concerned with environmental issues in strictest sense. Development and socioeconomic issues are also of importance. (IJIL4)

The example 9 belongs to Step $1 \mathrm{C}$ because it can be seen clearly that the author stated 'however' which indicates the researcher raised a question by the phenomena happening and problem in it.
Steps In Move 3

Table 4. Frequency of Steps of Move 3 in RA Introductions

\begin{tabular}{|c|c|c|}
\hline Step & Frequency & Percentage \\
\hline Step 1A & 2 & $13 \%$ \\
\hline Step 1B & 9 & $60 \%$ \\
\hline Step 2 & 1 & $7 \%$ \\
\hline Step 3 & 5 & $33 \%$ \\
\hline Step 4 & - & - \\
\hline $\mathbf{N = 1 5}$ & & \\
\hline
\end{tabular}

Table 4 shows the frequency and percentage of steps in Move 2 found in the RAs. From the results, Step $1 \mathrm{~A}$ is found in 2 articles (13\%), Step $1 B$ is found in 9 articles $(60 \%)$, Step 2 is found in only 1 article (7\%), Step 3 is found in 5 articles (33\%) and there is no Step 4 found in the articles. This clearly proved that the 15 articles of the three journals in the discipline of Law study written by international author dominantly used Step 1B in Move 3, that is Announcing Present Research.

\section{Example 10:}

To know the description of dividend policy, stock price, the value of the company and leverage at Sub-Sector of Pharmaceutical Company listed in Indonesia Stock Exchange. To know and analyze the influence of dividend policy and stock price to the value of the company at company of Pharmaceutical Sub Sector listed in Indonesia Stock Exchange simultaneously or partially. To know and analyze the influence of dividend policy and stock price to the value of the company with leverage as moderating variable at Sub-Sector of Pharmaceutical Company listed in Indonesia Stock Exchange simultaneously or partially.(IJLS-2)

The example 10 belongs to Step $1 \mathrm{~A}$ because it can be seen clearly that the author stated 'to know and analyze' which indicates the purpose of the research. 
Example 11:

This article examines the continuing relevance of tort law as a means of obtaining redress for environmental pollution in Nigeria. It seeks to answer the question of why despite the progress in the use of public law in the protection of the environment including the provision of a right to a satisfactory environment, Nigerians are still resorting to tort remedies in instances of environmental pollution. The principles of tort law that have been used to tackle environmental pollution include negligence, trespass, nuisance and the rules in Rylands v Fletcher.(IJLPR-2)

The example 11 belongs to Step 1B because it can be seen clearly that the author stated 'this article examines' which indicates the aims in terms of what the research researcher sets out to do or accomplish by doing the research.

\section{Example 12:}

This article examines the new and special administrative procedure that today governs the expulsion of foreigners in Mexico.This procedure includes the contributions made by international law and human rights to define and respect the rights of foreigners, as reflected in the new Reglementary Act of Article 33 of the Constitution, recently enacted by President Peña Nieto. The radical reform of the language of Article 33 was greatly facilitated by the "Human rights reform" made by President Calderon Hinojosa in his decree of June 10, 2011 that not only modified the name of Chapter I of the constitution but also introduced the notion of human rights throughout the constitutional text. (IIIL-3)

The example 12 belongs to Step 2 because it can be seen clearly that the author stated 'this procedure includes' which indicates the result of the findings and show that the result is the most important aspects of the research.

\section{Example 13:}

Nonetheless, if not much but at least a headway has been initiated by the Government with the passage of the Mental Healthcare Act 2016. This paper has been divided into four parts- Part Idiscusses the various issues, the challenges faced by persons suffering from mental disorder. Part II draws an analysis of the efforts made at the international arena especially by the WHO. Part III highlights the legislations on the issue which India had witnessed from 1912 to 2017 and Part IV concludes with the author's personal observation and suggestions. (IJLPR-4)

The example 13 belongs to Step 3 because it can be seen clearly that the author stated 'this paper has been divided into four parts' which indicates the structure of the paper.

\section{Pattern of Rhetorical Move and Step Analysis Result}

Research question number 3 asked about what common pattern of rhetorical move and step are used in introduction section of English Research Articles of Law Study.

Table 5 : Frequency of Rhetorical Moves and Steps Pattern

\begin{tabular}{|l|c|c|}
\hline \multicolumn{1}{|c|}{ Pattern } & Frequency & Percentage \\
\hline Complete & 7 & $47 \%$ \\
\hline Semi Complete & 6 & $40 \%$ \\
\hline Incomplete & 2 & $13 \%$ \\
\hline \multicolumn{1}{|c|}{$\mathbf{N}=\mathbf{1 5}$} & & \\
\hline
\end{tabular}

Table 5 shows the frequency and percentage of common moves. From the results, Complete pattern was found in 7 articles (47\%), Semi complete pattern was found in 6 articles (40\%), and Incomplete pattern was found in 2 articles (13\%). This proved clearly that the most common 
pattern moves and steps in the law 15 articles was complete pattern.

\section{Discussion}

The first finding in this research was about what moves dominantly found in RAs introoduction of Law Study written by international authors. The result showed that the dominant move found was Move 1 ( Establishing A Territory). The authors tended to give much about the phenomena of Law regarding the research area in introduction section. From the phenomena, the authors then raised question that will be discussed. The results implied that in Law Study research article introduction, move 1 was obligatory while moves 2 and 3 were conventional.

This is in line with the finding of a research in the field of Linguistics entittled 'Rhetorical Structure of Introduction in Applied Linguistics Research Articles' done by Rahman, dkk (2017) following CARS by Swales (1990). They found that the most dominant move was Move 1 (Establishing A Territory).

The second finding in this research was about what steps are dominantly found in RAs introoduction of Law Study written by international authors. The result showed that the dominant Step found was Step 2 of Move 1 (Making Topic Generalisation). The result implied that in Move 1, Step 2 was obligatory while the other was optional. In Move 2, all steps are optional while in Move 3 , Steps 1B was conventional and the others are optional. From this finding, we know that the authors mostly made topic generalisation which means they provided a lot about the phenomena and then got the problem based on the phenomena itself not from the previous study. It implied that most of the authors focus on their own research.

This is in line with the research done by Muhtadin and Noermanzah (2017) entitled 'Rhetorical Structure and Linguistics
Features in Introduction Part of Research in Indonesian Legal Science Journal.' Even the RAs authors were not native and the language was different, they found the authors did not really relate their research to the previous study.

The last finding in this research was about what are the common pattern of rhetorical move and step found in RAs introduction of law study written by international authors. Regarding the guidelines of each journals in which every articles have the same length, it is found that the most common pattern was complete pattern. From this finding, we know that the three journals almost have the same model. Swales' CARS (Create-aResearchSpace) model, in 1990 seems to be applicable in majority of Introductions in the RAs. In respect to the pattern of move structure, the results indicate that there is an overwhelming deviation from the CARS model compared to other fields like Applied Linguistics English RA written by Non-Native Speaker. A research entittled 'Rhetorical Structure of Introduction in Applied Linguistics Research Articles' done by Rahman, dkk (2017).

In the Law Studies RAs, first of all, they presented the background knowledge. In this part, they explained the definition of terms of law in research. Then they provided phenomena related to the background given. From the phenomena, the researcher raised the question. He found the problem from the phenomena happened or happening so that it must be discussed in research. After that, they explained what the research will particularly focus on or discuss about. The last, the structure of the paper will be presented in order the readers can understand the form of the article so that they will be hopefully interested to read the whole of it. 


\section{CONCLUSION AND SUGGESTION}

\section{Conclusions}

From the research results and discussion, several conclusions can be drawn from this study. It is found that the dominant move in introduction section of English RAs in Law Study written by international authors is Move 1 (Establishing a territory) regarding it is dominantly found with the biggest percentage. It is found that the most dominant step in introduction section of English RAs Law study written by international authors is Step 2 of Move 1 (Making Topic Generalisation) regarding it is dominantly found with the biggest percentage.

It is found that the most common pattern of compulsory moves and steps in the law 15 articles is complete pattern regarding it is dominantly found with the biggest percentage. Dominantly started by making topic generalisation, raising question, announcing present research, and indicating structure of the paper. From this finding, we can conclude that the three journals almost have the same model. The last but not least, the articles in the three journals are categorized into appropriate articles in term of discourse structure regarding the most dominant pattern found is the complete pattern.

\section{Suggestions}

Based on the conclusion above, it is suggested that first, It is suggested that students especially those whose major is law or anyone who wants to create research article of law study, should pay attention carefully to the acceptable pattern of rhetorical moves and steps in creating their research article especially the introduction section. It is because the introduction section will determine whether or not the readers are interested to read the whole article. So that the introduction section should be created as interesting as possible. It is considered really important as lectures and students of law study have to write article journal every year in their time of teaching and studying and publish them internationally. So that the findings of this research will help their English research articles especially in law study can be more acceptable and readable by English readers.

Second, It is suggested that lecturers can use this research as a reference material to teach Academic Writing and Discourse Analysis subject in order to make the students become more understand about these subjects, especially in topic of rhetorical style of moves and steps. Lectures or students are strongly encouraged to published articles to international journals. In addition, the Indonesian government through the directorate general of higher education also provides some funding for Indonesian scholars who will present a paper at an international conference or seminar which leads to a publication in an international journal.

The last but not least, It is suggested that the next researchers who want to conduct research in the same field to do the further research about the rhetorical style in the different object and context. They can use this study as their guidance to do further research. The next researchers are encouraged to do research especially about the language features used by the international authors. It is because English authors might use different language features in Law Study.

\section{REFERENCES}

Aprianti, D. (2017). The Citation Style In English Research Article Introductions Written By Indonesian Authors In Hard Sciences. Universitas Bengkulu.

Arsyad, S. (2013). A Genre-Based Analysis On The Introductions Of Research Articles Written By Indonesian Academics. Universitas Bengkulu. 
Arsyad, S. (2013). A genre-based analysis of Indonesian research articles in the social sciences and humanities written by Indonesian speakers. Bengkulu University

Arsyad, S. (2013). A Genre-Based Analysis on Discussion Section of Research Articles in Indonesian Written by Indonesian Speakers. Bengkulu University.

Bisri, S. 14 Februari 2016). Apa yang harus ditulis dalam sebuah latar belakang masalah.

(https://www.kompasiana.com/ww w.sugiantibisri.blogsot.com/apayang harus-ditulis-dalam-sebuahlatar-belakang masalah_56bfacc4ad7e610d0e4460 86) (diakses pada 15 Januari 2018)

Briones, RRY. (2012). Move Analysis of Philosophy Research Article Introductions Published in the University of Santo Tomas. University of Santo Tomas.

Chahal, Dana. (2014). Research Article Introductions In Cultural Studies: A Genre Analysis Exploration Of Rhetorical Structure. Victoria University, Australia.

Ishara, ER. (2016). Rethorical Structure Each Speaker Text in Grand Final WUDC 2009. Universitas Bengkulu. (Unpublished Thesis)

Kamaruddin, dkk (2013). Rhetorical Structure in Academic Research Writing by Non-Native Writers. Universiti Malaysia Perlis.

Miller, T. (1993). The discourse structure of research article introductions: Revisited with evidence from Arabic.

Muangsamai, P. 06 Maret 2018. Analysis of Moves, rhetorical patterns and linguistics features in new scientist articles. Kasetsart University, Thailand.
Muhtadin \& Noermanzah. (2017). Rhetorical Structure and Linguistics Features in Introduction Part of Research in Indonesian Legal Science Journal. STKIP PGRI Lubuk Linggau.

Penington, K. (2005). The Introduction Section. Helsinki University of Technology. (http://www.cs.tut.fi/kurssit/SGN16 006/academic_writing/cars_model_ handout.pdf ) (diakses pada 13 Januari 2018)

Rahman, dkk. (2017). Rhetorical Structure of Introduction in Applied Linguistics Research Articles. National University of Malaysia.

Reihan, A. 06 Februari 2015. Teori Retorika. (https://www.kompasiana.com/alanr eihan/teoriretorika_54f9014fa33311 a13d8b491a) (diakses pada 22 Januari 2018)

Rusdiansyah. 03 Desember 2016.Kajian Budaya Indonesia Pemahaman Retorika. (https://kajianbudayablog.wordpress .com/2016/12/03/pemahamanretorika/) (diakses pada 20 Januari 2018)

Shim, E. (2015). Introductions in Research Papers:Genre Analysis of Academic Writing. Sangji University.

Suryani, dkk. (4 November 2013). Rhetorical Structures in Academic Research Writing by Non-Native Writers. Universiti Malaysia Perlis \& Universiti Utara Malaysia, Malaysia.

Zaiontz, C. (2013). Real Statistik Using Excel Cohen's Kappa. http://www.realstatistics.com/reliability/cohenskappa/ (diakses pada 12 Februari 2018) 
Internet Source :

http://davidbeard.efoliomn.com/Uploads/Ma ster\%20Definitions\%20of\%20rhetor ic.pdf

http://rhetoric.sdsu.edu/resources/what_is_rh etoric.htm

http://libguides.usc.edu/writingguide/CARS

http://www.linguist.univ-paris-

diderot.fr/ amsili/Ens16/pdf/kappa8

70-140315104425-phpapp01.pdf

https://www.easycalculation.com/statistics/le arn-cohens-kappa-index.php 


\section{APPENDIX 1}

\section{List of RAs in the Corpus of the Study}

1. Chauhan and Guha (2015). "A Comparative Study of Constitutions of Germany, Austria and Switzerland," in International Journal of International Law, Volume 1 Issue 2.

2. Oyeyemi, Kolawole Kazeem (2016). "The Concepts Of Human Security In International Law: Implications For The Application And Protection Of Child Rights Globally And In Nigeria," in International Journal of International, Volume 2 Issue 2

3. Vargas, Jorge A (2015). "Expulsion Of Foreigners In Mexico: A Commentary on the New "Administrative Procedure of Exclusion" proposed by President Enrique Peña Nieto under the Reglementary Act of Article 33 of the Constitution," in International Journal of International Law, Volume 2 Issue 1.

4. Oyeyemi, Kolawole Kazeem (2017). "Human Environment And International Economic Law: Exploring The Importance Of Stockholm Declaration Of 1972" in International Journal of International Law ,Volume 3 Issue 1.

5. Islam, Md. Zahidul (2016). "Illegal Immigrants Of Bangladesh In Malaysia And Present Situation," in International Journal of International Law, Volume 2 Issue 2.

6. Bhardwaj, Vrinda (2018). "Adultery: A scandalous controversy? in International Journal of Lawand Policy Review, Vol.7 No.1.

7. Amechi \& Oni (2018). "Environmental Pollution,Common Law And The Continuing Relevance Of Torts Remedies In Contemporary Nigeria" in International Journal of Lawand Policy Review, Vol.7 No.1.

8. Nayak \& Khare1 (2018). "The War On Drugs Has Gone'Up In Smoke':Can Harm Reduction Reconcile Prohibition \& Tradition With Moderation?" in International Journal of Lawand Policy Review, Vol.7 No.1.

9. Khaute, MercyK (2018). "The Mental Health Care Act 2017- An Inclusive Approach To Health in India," in International Journal of Lawand Policy Review Vol.7 No.1.

10. Chandran \& Syaifudheen (2018). "Hard Cases Make Bad Law : Legality of United State's Unilateral Humanitarian Intervention in Syria," in International Journal of Lawand Policy Review, Vol.7 No.1.

11. Kraskovska, Anastasiia (2018). "Developing Pro-European Environmental and Climate Policy for Ukraine: Institutional Challenges, Appropriate Translation and Legal Compliance Scheme," in International Journal of Law and Society, Vol. 1, No. 2, 2018, pp. 64-71. 
12. Supitriyani (2018). "Dividend Policy and Stock Price to the Company Value in Pharmaceutical Company's Sub Sector Listed in Indonesia Stock Exchange," in International Journal of Law and Society. Vol. 1, No. 1, 2018, pp. 16-23.

13. Magani \& Gichure (2018). "Influence of Public Financial Management Reforms on Budget Implementation by Kenyan City Counties," in International Journal of Law and Society. Vol. 1, No. 2, 2018, pp. 46-63.

14. Hai,Tian (2018). "The Influence of MFN Clause on International Investment Dispute Settlement Procedure to Investor's Home Country" in International Journal of Law and Society. Vol. 1, No. 1, 2018, pp. 10-15.

15. Chukwu, Obinna Johnkennedy (2018). "The Press and Freedom of Information in Nigeria and the United States of America: An Analysis," in International Journal of Law and Society. Vol. 1, No. 1, 2017, pp. 24-33. 


\section{APPENDIX 2}

\section{An example of RA Introduction with a 'Complete Pattern' :}

\begin{tabular}{|c|c|}
\hline Moves and Steps & $\begin{array}{l}\text { Environmental Pollution, Common Law And The Continuing Relevance } \\
\text { Of Torts Remedies In Contemporary Nigeria }\end{array}$ \\
\hline $\begin{array}{l}\text { Move } 1 \\
\text {-Step } 2\end{array}$ & $\begin{array}{l}\text { Undoubtedly, the dumping of toxic waste in Koko, Delta State, in June } \\
\text { 1988, and the attendant public outcryagainst the adverse environmental } \\
\text { and human rights consequences was a watershed that culminated in the } \\
\text { establishment of modern environmental regulatory regime tailored } \\
\text { towards combating pollution and otheracts of environmental } \\
\text { degradation in Nigeria. Indeed, the Koko incident galvanised the Federal } \\
\text { Government to adopt legislative measures for the protection of the } \\
\text { environment in order to prevent further harms from being inflicted on } \\
\text { Nigerians.This was evident in the enactment of both the Harmful Waste } \\
\text { (Special Criminal Provisions etc.) } \\
\text { Environmental Protection Agency (FEPA) Act on } 30 \text { December1988. The } \\
\text { latter marked the advent of a comprehensive and nonpiecemeal } \\
\text { approach by the Federal government to the issue of environmental } \\
\text { protection. Indeed, the FEPA Act and subsequent amendments } \\
\text { facilitated the establishment by the Government through the then the } \\
\text { Federal Environmental Protection Agency (FEPA), of instruments to halt } \\
\text { environmental pollution and degradation in form of policies, standards, } \\
\text { guidelines and regulations. These environmental legislations are } \\
\text { preserved under the 1999 Constitution of the Federal Republic as acts } \\
\text { ofthe National Assembly. The same constitutional validity applies to } \\
\text { other existing legislations that are incidental to the protection of the } \\
\text { environment, as well as the African Charter on Human and Peoples. } \\
\text { Presently, the FEPA Act has been abolished and replaced by the National } \\
\text { Environmental Standards and Regulation Enforcement Agency (NESREA) } \\
\text { Act, as the principal framework environmental legislation in Nigeria. } \\
\text { Pursuant to the Act, the National Environmental Standards and } \\
\text { Regulation Enforcement Agency (NESREA), has adopted various } \\
\text { regulations for the control of environmental pollution and other acts of } \\
\text { environmental degradation. In addition, to effectively address incidences } \\
\text { of oil pollution in Nigeria, the Federal government enacted the National } \\
\text { Oil Spill Detection and Response Agency(Establishment)Act, which } \\
\text { established the National }\end{array}$ \\
\hline $\begin{array}{r}\text { Move } 2 \\
\text {-Step 1C }\end{array}$ & $\begin{array}{l}\text { It is therefore apparent that there exists constitutional, human rights } \\
\text { and environmental legislative frameworks for the protection of the } \\
\text { environment from pollution in Nigeria. The importance of these public } \\
\text { law frameworks lies not only in the provision of criminal sanctions and } \\
\text { civil remedies for the infringements of their provisions, but also in } \\
\text { certain circumstances, victims of environmental pollution or private } \\
\text { persons/organisations involved in the protection of the environment can }\end{array}$ \\
\hline
\end{tabular}




\begin{tabular}{|c|l|l|}
\hline & $\begin{array}{l}\text { petition the court for appropriate remedies. The question therefore is } \\
\text { why despite the explicit intervention of public law in the protection of } \\
\text { the environment, common law torts are still relevant as a veritable } \\
\text { source of remedies for Nigerians aggrieved by environmental pollution. } \\
\text { Indeed, most environmental complaints against transnational } \\
\text { corporations (TNC) and other companies operating in Nigeria are still } \\
\text { grounded in tort law.19 Admittedly, prior to the explicit intervention of } \\
\text { public law in the protection of the environment in Nigeria, common law } \\
\text { torts have been used in combating environmental pollution in Nigeria. }\end{array}$ \\
\hline - Step 1B & $\begin{array}{l}\text { This article examines the continuing relevance of tort law as a means of } \\
\text { obtaining redress for environmental pollution in Nigeria. It seeks to } \\
\text { answer the question of why despite the progress in the use of public law } \\
\text { in the protection of the environment including the provision of a right to } \\
\text { a satisfactory environment, Nigerians are still resorting to tort remedies } \\
\text { in instances of environmental pollution. The principles of tort law that } \\
\text { have been used to tackle environmental pollution include negligence, } \\
\text { trespass, nuisance and the rules in Rylands v Fletcher. }\end{array}$ \\
- Step 3 & $\begin{array}{l}\text { This article starts by examining the torts used in environmental } \\
\text { protection as well as the limitations inherent in these tort remedies. This } \\
\text { is followed by a discussion of the reasons why victims of environmental } \\
\text { pollution continue to rely on these torts as a means of obtaining redress } \\
\text { in Nigerian courts. It is argued that this is due to a combination of two } \\
\text { interrelated factors. Based on this, this article advocates for an express } \\
\text { recognition of a substantive right to a healthy environment in Nigeria. }\end{array}$ \\
\hline
\end{tabular}

An example of RA Introduction with a 'Semi Complete Pattern' :

\begin{tabular}{|c|l|}
\hline Moves and Steps & $\begin{array}{l}\text { The War On Drugs Has Gone 'Up In Smoke':Can Harm Reduction } \\
\text { Reconcile Prohibition And Tradition With Moderation? }\end{array}$ \\
\hline Move 1 & $\begin{array}{l}\text { Intoxication has been a hot topic of discussion and experimentation with } \\
\text { human beings since time immemorial. In contemporary society, } \\
\text { intoxicants world wide have been classified as legal and controlled / } \\
\text { regulated substances ; certain intoxicants are permitted to be used } \\
\text { recreationally and clinically, whereas the use, manufacture, or } \\
\text { possession of others carries punishment. } \\
\text {-Step 2 }\end{array}$ \\
$\begin{array}{l}\text { Psychoactive substances have been well defined by modern science, and } \\
\text { include within their number several every-day consumables. These } \\
\text { include various strains of caffeine found in coffee, tea or chocolate, } \\
\text { nicotine in tobacco, and several other plant extracts that include } \\
\text { psilocybin, opium and morphine. The 1940s saw the creation of several } \\
\text { synthetics, such as LSD and MDMA.All psychoactives without exception } \\
\text { can beused as medicines, for physical diseases or in therapy, yet in } \\
\text { stronger concentrations, these can be used recreationally. Prohibition is } \\
\text { aimed at preventing "use of substances primarily for their psychoactive } \\
\text { effect outside of aclinical situationor doctor's care". Still, most }\end{array}$ \\
\hline
\end{tabular}




\begin{tabular}{|c|c|}
\hline & $\begin{array}{l}\text { prohibitionist laws make pharmaceutical or research use so heavily } \\
\text { regulated that for at least the last } 50 \text { years, research into and the } \\
\text { medical use of most psychoactive substances has come to a slowcrawl. } \\
\text { A government may seek to control a drug where it perceives that use of } \\
\text { certain substances causes detrimental effects to its users or to society. } \\
\text { Control is exercised through making usage, possession, or manufacture } \\
\text { illegal by law; such forms of control are known as "prohibition", and } \\
\text { usually carry criminal penalties. As an alternative to prohibition, "harm } \\
\text { reduction" is a proposed model, which seeks to educate those engaged } \\
\text { in activities considered taboo in society, by educating them about the } \\
\text { associated dangers and allowing an individual free will as to whether or } \\
\text { not he/she will engage in such an activity. }\end{array}$ \\
\hline $\begin{aligned} \text { Move } 3 \\
\text { - Step 1B }\end{aligned}$ & $\begin{array}{l}\text { This paper seeks to perform an analysis of both instruments of policy } \\
\text { making, and suggest balanced models for countries where there has } \\
\text { been traditional use of psycho active substances. }\end{array}$ \\
\hline
\end{tabular}

An example of RA Introduction with a 'Incomplete Pattern' :

\begin{tabular}{|c|l|}
\hline Moves and Steps & $\begin{array}{l}\text { The War On Drugs Has Gone 'Up In Smoke':Can Harm Reduction } \\
\text { Reconcile Prohibition And Tradition With Moderation? }\end{array}$ \\
\hline -Step 2 & $\begin{array}{l}\text { Marriage is a holy union between a man and a woman for the purpose of } \\
\text { procreation. It is also called matrimony or wedlock, is asocially orritually } \\
\text { recognized union between spouses that establishes rights and } \\
\text { obligations between them, between them and their children, and } \\
\text { between them and their in-laws. Marriage cannot be given one meaning } \\
\text { or a restrictive definition, owing to the fact that it has different } \\
\text { connotation in every culture. Even within the western communities, } \\
\text { definitions of marriage have careened from one extreme to an other and } \\
\text { every where in between. } \\
\text {-Step 3 }\end{array}$ \\
$\begin{array}{l}\text { Edmund Leach is a renowned anthropologist who has severely criticized } \\
\text { the definitions of other thinkers as being too narrow or restrictive. He } \\
\text { states that marriage is not explicable within the parameters of one } \\
\text { definition because it consists of a series of rights arising from it. These } \\
\text { rights include sexual monopoly, legality of children, joint fund for } \\
\text { property to benefit the children, etc. 4 Thus; the concept of "sexual } \\
\text { monopoly" is of paramount importance within the realms of marriage. } \\
\text { However, this fact is arguable as Polygamy is practices in many cultures } \\
\text { like Islam till date. } \\
\text {-Step 2 } \\
\begin{array}{l}\text { Focusing on the importance of sexual monopoly, one might question its } \\
\text { significance in a marriage. Why is virginity protected before marriage }\end{array}\end{array}$ \\
\hline
\end{tabular}


and adultery prohibited thereafter? Why is sex outside marriage against the principle of aestheticism? This can be attributed to the fact that adultery is not only frowned upon by the church since time immoral but promiscuous amour have a risk of illegitimate progeny which complicates the functioning of any household and disrupts the norms of the society.

Sex with an individual outside marriage is a ticket to divorce because it is not just an infringement of the rights but also a trust. Marriage is a fiduciary relationship based on trust and mutual respect. The social implications associated with adultery are not the sole reason for its denunciation, the fact that coitus is benevolent interaction between a husband and his wife makes a positive contribution to the excellence of domesticlife. If not sexual monopolythen our societyshould accept sexual liberty at the cost of what? The highest satisfaction of sex is by Monogamy. It is imperative for this holy sacrament called marriage to survive without the feeling of insecurity, jealousy and humiliation fuelled by the evils associated with adultery. Thus, the conception of any marriage where the element of will commitment is perceptibly absent would result in an anticlimax. 